\title{
Deposit Collapse and Landslide Stability Analysis
}

\author{
Xiaoqin $\mathrm{He}^{1, \mathbf{a}^{*}}$,Yunwei Meng ${ }^{2, \mathrm{~b}}$ \\ b514346081@qq.com. \\ China Merchants Chongqing Communications Research \& Design Institute Co., Ltd, Chongqing, \\ 400067, China
}

Key words: collapse deposit; landslide; combination; the stability calculation

Abstract: According to the meteorological characteristics of deposit a collapse and landslide characteristics, topography, stratum lithology, geological structure and characteristics and hydrogeological conditions of the earthquake pointed out that the landslide happened under the combination of internal and external factors of sliding, and stability calculation method is proposed, for the subsequent engineering management providing an important theoretical base.

\section{overview}

Deposit collapse and landslide due to its unique forming conditions, is different from the general landslide in landslide formation.On the project treatment, we should start from the aspects of the formation of its internal mechanism analysis first of all,then we can put forward to the scientific and reasonable treatment scheme.

\section{Project summary}

Tang village bridge area located in southwest China, is one of the important control points on the highway engineering, bridge aslant across a seasonal gully and head down the river, small range direction line to $70^{\circ}$, great mileage ${ }^{\circ} 57$ line direction.Located in the bridge area mileage K52+ $520 \sim \mathrm{K} 52+610$ position there exists a collapse deposit. Colluvial deposit body length is about $90 \mathrm{~m}$, an average of $65 \mathrm{~m}$ wide, thick $6 \mathrm{~m}$, volume of $35100 \mathrm{~m}^{3}$.It is located the area on the left side of the bridge, round-backed armchair, the main influence of the left line of tang village bridge 2 \# \#, 5 \# bridge pier; the right line 9 \#, 10 \# pier.Colluvial deposit body is mainly composed of sandstone stone, gravel and clay, stone than about 3:7, slightly Micronesia, and wet.

\section{Engineering geological conditions}

\section{The weather characteristics}

Landslide areas belong to subtropical humid monsoon climate zone, mild climate, rainfall humid climate. It was different in regional climate and three-dimensional climate characteristics are outstanding.At the same time, the summer is drought, low temperature, continuous rain, hail, wind, cold wave, etc. Severe weather is also more frequent.

According to the meteorological data,the four seasons are very distinct.The climate is warm in winter;drought in summer;foggy.In early spring, the rise of temperature is quickly and instability.Autumn is long and rainy. The sunshine is abundant and frost-free period is long, so frost and snow is rare.The annual average wind speed is $1.40 \mathrm{~m} / \mathrm{s}$, and the annual maximum wind speed is $15.00 \mathrm{~m} / \mathrm{s}$.Bridge site stretches across a seasonal gully and head down the river.The water of gully is about $0.05 \mathrm{~L} / \mathrm{s}$ in investigation period.Head down river survey and period of water is about $15 \mathrm{l} / \mathrm{S}$ 
and is the main surface water in bridge area.Survey level is $518.05 \mathrm{~m}$ and the highest flood level is $520.15 \mathrm{~m}$.

\section{Topography}

Bridge site area belongs to low tectonic denudation mountain landform area.Bridge central distribution is along the natural slope.Southeast, northwest is high on both sides.Gully and valleys position of the head down river is low,and bridge small mileage abutment slope is steep, horizontal ground slope Angle generally $35^{\circ} \sim 40^{\circ}$, which local position can reach $55^{\circ}$ and large range of the abutment slope position is relatively flat, generally $20^{\circ} \sim 25^{\circ}$.

The proposed bridge inclined across a seasonal gully and head down the river;bridge site's lowest ground elevation is located in the head down river valley, height of $502.32 \mathrm{~m}$ and peak is located on the north of the bridge area at the top of the slope, height of $640.38 \mathrm{~m}$; the relative height is about $138.06 \mathrm{~m}$.

\section{The formation lithology}

According to the geological annotation and drilling,bridge location distribution formation mainly is quaternary remnants diluvial layer, colluvial deposit and diluvial layer, one of triassic middle badong groupand lower triassic jialing river group of four.Now state the layers of rocks from new to the old :

The quaternary remnants diluvial layer $\left(\mathrm{Q}_{4}{ }^{\mathrm{el}+\mathrm{dl}}\right)$

Red clay:tan, plastic shape, knife cuting surface is smooth, high strength and high toughness,no shaking shock responses, containing 10\% limestone rubble, gravel size generally $15 \sim 40 \mathrm{~mm}$, angular.which scattered in the bridge area.

Quaternary holocene colluvial deposit $\left(\mathrm{Q}_{4}{ }^{\mathrm{c}+\mathrm{dl} l}\right)$

Stone soil's color is mainly composed of red stone, gravel, clay, etc;block, gravel size generally 20 to $300 \mathrm{~mm}$, content accounted for about $60 \%$,parent rock for limestone, angular shaped;Clay filling, meanwhile, accounts for about $40 \%$, uneven distribution.

Quaternary diluvium $\left(\mathrm{Q}_{4}{ }^{\mathrm{c}+\mathrm{dl}}\right)$

Pebble soil: gray, is mainly composed of sandstone pebbles and boulders, pebble accounted for about 50\%, block $40 \sim 200 \mathrm{~mm}$ diameter, boulders accounted for about 30\%, block size of $240 \sim$ $360 \mathrm{~mm}$, clay and sand filling period;Drift stone mill pebble, roundness, the angular and the cone, grading is poor.Position the layers are mainly distributed in head down the river bed, the investigation did not reveal to the layer in drilling.

The Triassic middle badong group $\left(\mathrm{T}_{2 \mathrm{~b}}{ }^{1}\right)$

Are very lithology is mainly for the marl, described as follows:

Marl: pale yellow, mud crystal structure, structure of thick layers, is mainly composed of calcite, clay mineral, local high shale content.Drilling reveal the maximum thickness of $17.50 \mathrm{~m}$ (ZK3).

Limestone breccia shape(karst breccia) : gray, gray, dark gray, microcrystalline structure, brecciated structure,Breccia ingredient for limestone, grain size $5 \sim 35 \mathrm{~mm}$, argillaceous cementation, calcium cementation is better.Drilling reveal the maximum thickness of $15.80 \mathrm{~m}$ (ZK32).

\section{Geological structure and earthquake}

Tang village bridge located in the northern west wing party doosan anticline, are very fold development, local overturned stratum,Zhongxian strata occurrence around $315 \sim 335^{\circ}<40 \sim$ $315^{\circ}, \mathrm{K} 52+280 \sim \mathrm{K} 52+455$ section of rock fall halt production of $140 \sim 150^{\circ}<60 \sim$ $150^{\circ}$, Wanzhou strata occurrence around $320^{\circ} \sim 330^{\circ}<50$ to 55, through no fault near the bridge area.According to engineering geological mapping and drilling, surface are very fissure 
development, according to the rock outcrop measurement statistics, the bridge area main development four tectonic fractures:

Small range direction:

occurrence $46^{\circ}, 246^{\circ}<$ micro shape, surface flat, $1.0 \sim 1.5 \mathrm{~m}$, spacing of $0.8 \sim 1.2 \mathrm{~m}$;

occurrence $49^{\circ}, 75^{\circ}<$ closed shape, surface flat, $1.2 \sim 2.3 \mathrm{~m}$, spacing of $1.0 \sim 2.2 \mathrm{~m}$. Fracture combined with general, is a rigid structure.Big range direction;

Big range direction:

occurrence $^{\circ}, 235^{\circ}<65$ micro shape, surface flat, $1.1 \sim 1.2 \mathrm{~m}$, spacing of $0.5 \sim 0.8 \mathrm{~m}$;

occurrence $37^{\circ}, 105^{\circ}<$ closed form, surface flat, $1.0 \sim 2.0 \mathrm{~m}$, spacing of $0.8 \sim 1.2 \mathrm{~m}$. Fracture combined with general, is a rigid structure.

Through calculation, average shear wave velocity field soil nu se $=190 \mathrm{~m} / \mathrm{s}$, the maximum thickness of $2.10 \mathrm{~m}$, covering for bridge engineering site category I classes, design feature period value of $0.25 \mathrm{~s}$, seismic favorable location.

Hydrogeological conditions

Are very groundwater mainly for quaternary pore water and karst fissure water.

Quaternary pore water mainly by atmospheric rainfall recharge, runoff way short, atmospheric precipitation in the form of surface flow to the area in central side drain low-lying place.

Karst fissure water, mainly by atmospheric precipitation and surface water supplies,its rich degree of water level of karst development, connectivity and control landform.For main recharge source of groundwater, atmospheric precipitation rainfall most along the slope, slope drainage in the central gulley and head down the river,a few along the slope eluvial soil porosity and rock porosity, fracture infiltration recharge of groundwater.

The groundwater quantity of above all, are very poor.Site groundwater decomposition composite class, crystallization, decomposition of no corrosion.

Bad geological phenomenon and its influence on adjacent structures

Colluvial product stability calculation, selection of stone soil $\mathrm{C}$, phi values based on the colluvial deposit body containing a small piece of gravel soil actual situation and local experience in chongqing comprehensive values:Take on the natural gravity of $21.0 \mathrm{KN} / \mathrm{m} 3$, saturated severe take 21.5 KN/m3; Shear strength index of natural take C: $38.0 \mathrm{kpa}$, phi: $17.2^{\circ}$; Shear strength indexes of saturated take C: $35.0 \mathrm{kpa}$, phi: $14.8^{\circ}$. The stability calculation parameters are shown in table 1.

Table1 colluvial soil stability calculation parameter selection table

\begin{tabular}{|c|c|c|c|c|c|c|}
\hline \multirow{2}{*}{$\begin{array}{c}\text { name of the } \\
\text { geotechnical }\end{array}$} & \multicolumn{2}{|c|}{ Severe sliding body } & \multicolumn{3}{c|}{ shear strength of slide face } \\
\cline { 2 - 6 } & natural & saturation & $\mathrm{C}(\mathrm{KPa})$ & $\varphi\left(^{\circ}\right)$ & $\mathrm{C}(\mathrm{KPa})$ & $\varphi\left({ }^{\circ}\right)$ \\
\cline { 2 - 7 } & $21.0^{*}$ & $21.5^{*}$ & 38.0 & 17.2 & 35.0 & 14.8 \\
\hline $\begin{array}{c}\text { mass rock } \\
\text { and soil }\end{array}$ & natural state & \multicolumn{2}{c|}{$\begin{array}{c}\text { saturation } \\
\text { condition }\end{array}$} \\
\hline
\end{tabular}

Selection calculation according to the status quo of the terrain conditions, after the trial calculation and analysis cut out the most unfavorable conditions;;Main consideration in the calculation of two kinds of working condition, storm conditions in natural state.The transfer coefficient method is adopted to calculate.According to the results of the survey of construction 
drilling, colluvial integrated the bedrock are angled mansard, using limit equilibrium theory of linear sliding surface transfer coefficient method to evaluate the stability of the colluvial deposit body and thrust.

According to the engineering of the importance of the status quo: evaluation of the safety factor of natural state take FSt $=1.20$, saturated state take FSt $=1.15$. The results summary are shown in table 2 .

Table 2 K52 + 520 + 610 K52 colluvial soil stability calculation summary table

\begin{tabular}{|c|c|c|c|c|c|c|c|c|}
\hline & $\begin{array}{l}\text { Calcul } \\
\text { ate } \\
\text { Sectio } \\
\text { n }\end{array}$ & $\begin{array}{l}\text { Calculat } \\
\text { ion } \\
\text { conditio } \\
n\end{array}$ & Status & $\begin{array}{c}\text { Safety } \\
\text { Coeffici } \\
\text { ent }\end{array}$ & $\begin{array}{c}\text { Stabili } \\
\text { ty } \\
\text { factor } \\
\text { FS }\end{array}$ & $\begin{array}{c}\text { The } \\
\text { remainin } \\
\mathrm{g} \\
\text { decline } \\
\text { in force } \\
(\mathrm{KN} / \mathrm{m})\end{array}$ & $\begin{array}{l}\text { Stable } \\
\text { Status }\end{array}$ & $\begin{array}{c}\text { Rema } \\
\text { rk }\end{array}$ \\
\hline \multirow{2}{*}{$\begin{array}{l}\text { She } \\
\text { ar } \\
\text { exp } \\
\text { ort } 1\end{array}$} & \multirow[b]{2}{*}{ B-B' } & \multirow[b]{2}{*}{$\begin{array}{c}\text { Situatio } \\
\text { n } \\
\text { terrain }\end{array}$} & Weight & 1.20 & 1.387 & 0 & Stable & \\
\hline & & & $\begin{array}{c}\text { Weight } \\
\text { +rainsto } \\
\text { rm }\end{array}$ & 1.15 & 1.162 & 0 & Stable & \\
\hline \multirow{2}{*}{$\begin{array}{l}\text { She } \\
\text { ar } \\
\text { exp } \\
\text { ort } 2\end{array}$} & \multirow[b]{2}{*}{ B-B' } & \multirow[b]{2}{*}{$\begin{array}{c}\text { Situatio } \\
\text { n } \\
\text { terrain }\end{array}$} & Weight & 1.20 & 1.206 & 0 & Stable & \\
\hline & & & $\begin{array}{l}\text { Weight } \\
\text { rainstor } \\
\mathrm{m}\end{array}$ & 1.15 & 1.061 & 0 & $\begin{array}{c}\text { Basica } \\
\text { lly } \\
\text { stable }\end{array}$ & \\
\hline
\end{tabular}

Summary: K52 + 610 + 520 K52 colluvial deposit body:B - B 'section the stability of the colluvial deposit soil under the condition of the status quo of the terrain, cut export 1 the stability coefficient of natural conditions:FS=1.387, Soil slope is stable;Heavy rain conditions: the stability of soil slope under the condition of the coefficient. Proposed tang village bridge of the left line 2 \# 4 \#, 5 \# bridge pier;The right line 9 \#, 10 \# pier if using artificial dig-hole pile foundation.This research suggestion: plan 1, in K52 + 520 + 610 K52 colluvial integrated bridge pier upper setting anti-slide retaining wall, and then carries on the bridge pile foundation construction;Scheme 2, for the colluvial deposit shall be clear and the volume of $35100 \mathrm{~m} 3$.Also suggested that the colluvial deposit body within the scope of the pier foundation USES the artificial dig-hole pile, if using drilling pile, impact drill recommended to do homework, so as not to make the construction of water into the colluvial deposit body, affect the colluvial product stability.

\section{Conclusion}

This deposit collapse and landslide treatment scheme put forward, is based on the comprehensive analysis of the internal factors of landslide and the role of external influence, which is operable and provides the beneficial reference for similar projects.

\section{Acknowledgements}

This work was funded by National and local joint engineering laboratory of traffic Civil Engineering Materials of Chongqing Jiaotong University (No. LHSYS-2013-007). It was also funded by Guizhou Transportation Scientific and Technology Project of Guizhou Provincial Transportation Department (No. 2015-121-035). 


\section{References:}

[1] Qing Xu, Weiming Wang, Shenghong Chen. Numerical analysis of rock slope stability and comprehensive comparison [J]. Rock Mechanics and Engineering, 2008,27 (A02).(in Chinese)

[2] Yu Zhao, Tiecheng Wang, Weichao Li , Fuchu Dai. Expressway Landslide Stability Evaluation and Treatment Simulation [J]. Rock Mechanics and Engineering, 2008,27 (11).(in Chinese)

[3] Henghe Peng. Embankment Slope Failure Investigation and stability analysis of practice [J]. Highway Engineering, 2008,33 (3).(in Chinese)

[4] Chuansheng Chen, Jianmin Zhang, Shizhi Wen . Slip zone based on the effective vertical stress level of strength parameters Applicability [J]. Rock Mechanics and Engineering, 2011,30 (8).(in Chinese)

[5] Xinghua $\mathrm{Xu}$, Yuequan Shang, Yingchao Wang. Debris landslide comprehensive management and evaluation and decision method method [J]. Jilin University: Earth Sciences, 2011,41 (2).(in Chinese) 